\title{
Analisis Pengukuran Kualitas Layanan Website LP2M UIN Raden Fatah Palembang Menggunakan Metode Webqual 4.0
}

\author{
Rahmawati \\ Fakultas Sains dan Teknologi \\ Universitas Islam Negeri Raden Fatah Palembang \\ Email: rahmaawati1996@gmail.com \\ Saipul Anwar \\ Fakultas Sains dan Teknologi \\ Universitas Islam Negeri Raden Fatah Palembang \\ Email: saipulanwar@radenfatah.ac.id
}

\begin{abstract}
Abstrak
Layanan kualitas suatu website perlu diukur berdasarkan tingkat kepuasan pengguna. Pengukuran kualitas layanan website LP2M UIN Raden fatah Palembang belum pernah dilakukan. Model penelitian yang digunakan adalah WebQual 4.0. Uji validitas dan reliabilitas dilakukan untuk memperoleh data yang valid dan reliabel. Teknik analisis data yang digunakan adalah analisis korelasi sederhana. Pada penelitian diajukan 3 hipotesis. Hasil penelitian menunjukkan bahwa ketiga hipotesis mempunyai hubungan yang signifikan pada kepuasan pengguna (User Satisfaction /Overall), dengan korelasi antar variabel yang diteliti tergolong lemah positif. Dankontribusi yang disumbangkan dari seluruh variabel sebesar $44,1 \%$. Total keseluruhan pengukuran kualitas layanan website sebesar 3,87 yang berada pada skala setuju bahwa kualitas layanan website LP2M UIN Raden Fatah Palembang sudah sesuai dengan kepuasan pengguna. Dari hasil penelitian sebagai masukkan bagi pihak pengembang kualitas layanan website LP2M untuk menggunakan kombinasi framework lainnya agar dapat dilakukan perbaikan untuk lebih meningkatkan kualitas layanan kedepannya.
\end{abstract}

Kata Kunci: Pengukuran Kualitas, Kepuasan Pengguna, Korelasi Sederhana, WebQual 4.0

Dalam era globalisasi ini, hampir seluruh pihak (swasta maupun pemerintah) memanfaatkan teknologi untuk mengoptimalkan pelayanan mereka. Dengan dukungan sistem informasi yang baik maka sebuah lembaga pendidikan akan memiliki berbagai keunggulan kompetitif sehingga berdaya saing tinggi. Sistem informasi berperan sebagai alat bantu untuk memudahkan pengelolaan suatu sumber daya yang dimiliki oleh suatu lembaga.

Website LP2M UIN Raden Fatah Palembang berfungsi sebagai sarana penyampaian informasibaik untuk mendukung kinerja pegawai, Dosen maupun memberikan layanan kepada mahasiswa-mahasiswi yang akan mengikuti kegiatan KKN. Sehingga menghasilkan informasi yang berguna serta meningkatkan kemampuan peran serta dosen dan mahasiswa dalam penelitian dan pengabdian masyarakat. Website LP2M sudah lama diterapkan, namun pada bulan November 2016. Website dilakukan perubahan ulang keseluruhan, yaitu LP2M menerapkan fitur E-KKN pada website. Hingga saat ini website masih terus dikembangkan dan digunakan di LP2M UIN Raden Fatah Palembang. Website LP2M beralamatkan di http://lp2m.radenfatah.ac.id/.

WebQual 4.0 yang pertama kali dikembangkan oleh Barnes (1998) merupakan suatu pengukuran untuk mengukur kualitas website berdasarkan instrumen- instrumen 
penelitian yang dapat dikategorikan kedalam empat variabel dalam mengukur kualitas layanan website, yaitu variabel Kegunaan (Usability), Variabel Kualitas Informasi (Information Quality), variabel Kualitas Interaksi Layanan (Service Interaction Quality), dan variabel overall disini lebih diartikan sebagai overall terhadap User Satisfaction (Kepuasan Pengguna) dan berperan sebagai variabel dependen. Sehingga keempat variabel ini nantinya dapat dijadikan acuan untuk mengetahui kualitas dari penerapan website LP2M UIN Raden Fatah Palembang dengan menguji variabel-variabel yang manakah mempunyai hubungan pada kepuasan pengguna/overall.

Beberapa fitur ayanan informasi pada website yang dapat diakses antara lain fitur penelitan, pengabdian, profile, PSGA, sertifikat, E-Journal, E-KKN dan informasi lainnya yang perlu di update data setiap harinya untuk mendapatkan informasi yang relevan dan akurat. Mengingat banyaknya peserta mahasiswa-mahasiswi yang mengikuti kegiatan KKN yang harus mengakses ke website LP2M serta staf pegawai LP2M yang mengakses ke website untuk mengerjakan tugas nya, ditambah lagi dosen DPL yang akan mendaftarkan diri sebagai dosen DPL maupun yang sudah mendaftarkan sebagai dosen DPL dan akan menginputkan nilai mahasiswa-mahasiswi yang telah mengikuti kegiatan KKN.

Dalam operasional pelayanan tidak dapat dihindari terjadinya suatu kesalahan maupun gangguan teknis. Sehingga membuat pengambilan keputusan dalam pelayanan yang diberikan akan menjadi lama serta informasi yang dihasilkan kurang akurat. Untuk meningkatkan efisiensi dan efektifitas pada website, maka pengelola website dituntut memiliki kemampuan merancang dan mengelola website dengan baik dan optimal, agar website yang dikelola berkelanjutan dan senantiasa digunakan para pengguna. Serta menghasilkan suatu informasi yang lebih akurat, tepat waktu serta relevan.

Layanan kualitas suatu website perlu diukur berdasarkan tingkat kepuasan pengguna untuk mengetahui, memperhatikan, dan menentukan langkah-langkah yang dibutuhkan selanjutnya terkait dengan kualitas layananwebsiteyang diharapkan oleh pengguna sistem. Hal ini penting dilakukan mengingat belum pernah dilakukan penelitian mengenai analisis kualitas layanan website LP2M. Maka diperlukan analisa tentang pengukuraan kualitas layanan website LP2M UIN Raden Fatah Palembang.

\section{Kerangka Teori}

\section{WebQual}

WebQual merupakan salah satu metode atau teknik pengukuran kualitas website berdasarkan persepsi pengguna. WebQual sudah mulai dikembangkan sejak tahun 1998 dan telah mengalami beberapa interaksi dalam penyusunan dimensi dan butir pertanyaannya. Hingga versi 4 saat ini. Metode ini merupakan pengembangan dari ServQual yang banyak digunakan sebelumnya pada pengukuran kualitas jasa [1].

a. WebQual 1.0

WebQual 1.0merupakan versi pertama dari instrumen WebQual yang dikembangkan dalam domainwebsite sekolah bisnis di UK (United Kingdom) dengan diselenggarakannya sebuah lokakarya denganmelibatkan enam siswa Master sebagai delegasinya. Hal yang dibahas pada diskusi tersebut adalah: 
“Apa sajakualitas website dari sekolah bisnis yang sangat baik?”. Setelah melalui proses analisis tersisa 23 pertanyaanyang lalu kemudian dikelompokkan kedalam empat dimensi utama yaitu kemudahan penggunaan (ease of use), (pengalaman experience), informasi (information), komunikasi (communication) dan integrasi (integration).

b. WebQual 2.0

WebQual 2.0diterapkan pada website B2C (Business to Consumer) yang menunjukkan dengan jelas bahwa perspektif interaksi kualitas dari suatu website tidak terwakili dengan baik pada WebQual 1.0. Pada WebQual 2.0 ini ditambahkan aspek kualitas interaksi dengan mengadaptasi hasil kerja dari ServQuaL dan diaplikasikan pada domain toko buku online.

c. WebQual 3.0

Pada WebQual 3.0 indikator-indikator kualitas dikategorikan kedalam tiga kategori utama, yaitu: kualitas website, kualitas informasi dan kualitas interaksi. Ketika WebQual 1.0 begitu kuat pada kualitas informasinya namun kurang kuat pada interaksi layanannya. Begitu juga dengan WebQual 2.0 yang menekankan kualitas interaksi namun menghilangkan beberapa kualitas informasi dari WebQual 1.0. Versi baru dari WebQual 3.0 ini diujicobakan pada domain lelang online.

d. WebQual 4.0

WebQual 4.0 merupakan hasil analisis pada WebQual 3.0 yang membawa pada identifikasi tiga dimensi dari kualitas website e-commerce, yaitu: kegunaan (usability), kualitas informasi (information quality) dan kualitas layanan interaksi (service interaction quality). Dalam WebQual 4.0 ini, kegunaan berkaitan dengan desain website misalnya penampilan, kemudahan penggunaan, navigasi dan juga tampilan yang disampaikan dalam website tersebut. Kegunaan fokus pada pandangan bagaimana pengguna melihat dan berinteraksi dengan website: apakah mudah bernavigasi? Apakah desain sesuai dengan jenis website? Lalu kualitas informasi merupakan kualitas dari isi website, yaitu kesesuaian informasi untuk penggunanya seperti format, tingkat akurasi dan juga relevansi. Terakhir ada kualitas layanan interaksi yang merupakan hal yang dialami oleh pengguna website, diwujudkan dalam bentuk kepercayaan dan empati misalnya mengenai transaksidan keamanan informasi, pengiriman produk, personalisasi dan komunikasi dengan pemilik atau pengelolawebsite.

Menurut penelitian Tarigan [2] yang menggunakan teori WebQual (Barnes dan Vidgen) dan teori kepuasan pengguna akhir (Doll dan Torkzadeh). Untuk mengevaluasi kepuasan pengguna (user satisfaction) dan memeriksa instrumen pada variabel WebQualyang dinilai oleh pengguna e-library pada stock exchange of Thailand (SET). Analisis disusun dari satu set data dengan 341 responden, dari sistem e-library pengguna akhir akan mengkonfirmasi beberapa hubugan positif antara dimensi WebQual dan kepuasan pengguna. 


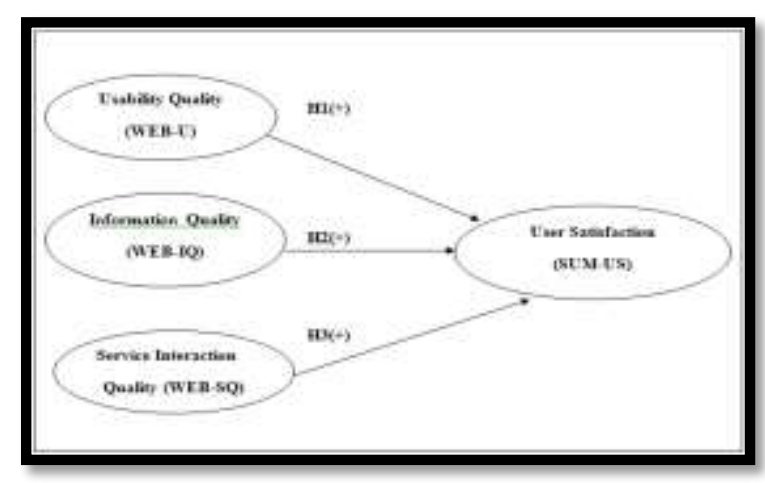

Gambar 1. Model Konseptual WebQual 4.0

Berdasarkan model konseptual, penelitian ini memiliki hipotesis:

H1: Terdapat hubungan positif antara kegunaan dan kepuasan pengguna.

$\mathrm{H} 2$ : Terdapat hubungan positif antara kualitas informasi dan kepuasan pengguna.

H3: Terdapat hubungan positif antara interaksi kualitas layanan dan kepuasan.

\section{WebQual 4.0}

Sesuai dengan masalah dan tujuan penelitian, variabel penelitian terdiri dari 4 variabel, antara lain Usability (Kegunaan), Information Quality (Kualitas Informasi), Service Interaction Quality (Kualitas Interaksi) dan Kepuasan Pengguna (User Satisfaction/Overall). Dalam penelitian ini terdapat beberapa kriteria yang dipakai dengan indikatornya, yaitu:

a. Usability (Kegunaan)

Usability adalah mutu yang terkait dengan website, contohnya tampilan, kemudahan dalam penggunaan, navigasi dan suatu gambaran yang disampaikan kepada pengguna. Dalam hal ini, tampilan sebuah website merupakan factor utama dalam mempengaruhi pengunjung website. Dengan desain yang menarik, kemudahan dalam penggunaan, hal ini dapat membuat pengunjung atau pengguna website senang untuk mengunjungi dan akan mudah dalam dalam memperoleh informasi yang dibutuhkan.

Indikator Usability yaitu 1) Saya menemukan situs mudah dipelajari untuk beroperasi; 2) Interaksi saya dengan situs ini jelas dan bisa dimengerti; 3) Saya menemukan situs yang mudah dinavigasi; 4) Saya menemukan situs yang mudah digunakan; 5) Situs ini memiliki tampilan yang menarik; 6) Desainnya sesuai dengan jenis situs; 7) Situs tersebut menyampaikan rasa kompetensinya; dan 8) Situs ini menciptakan pengalaman positif bagi saya

b. Kualitas Informasi (Information Quality)

Information Quality adalah kualitas yang dilihat dari isi yang terdapat pada web, berdasarkan pantas atau tidak informasi yang disajikan untuk tujuan pengguna seperti akurasi, format dan keterkaitannya.

Indikator Information Quality yaitu 1) Memberikan informasi yang akurat; 2) Menyediakan informasi yang dapat dipercaya; 3) Memberikan informasi tepat waktu; 4) Menyediakan informasi yang relevan; 5) Memberikan informasi yang 
mudah dimengerti; 6) Memberikan informasi pada tingkat detail yang tepat; dan 7) Menyajikan informasi dalam format yang sesuai

c. Kualitas Interaksi Layanan (Service Interaction Quality)

ServiceInteraction Quality adalah mutu dari interaksi pelayanan yang telah dialami oleh pengguna ketika mereka mengakses ke dalam website, yang terwujud dengan kepercayaan dan empati. Kualitas interaksi mencakup kemampuan memeberi rasa aman saat interaksi, memiliki reputasi yang baik, memudahkan komunikasi, menciptakan perasaan emosional yang lebih personal, memiliki kepercayaan dalam menyimpan informasi pribadi pengguna, menciptakan komunitas yang lebih spesifik, mampu memberi keyakinan bahwa janji yang disampaikan akan ditepati.

Indikator dari ServiceInteraction Quality yaitu 1) Memiliki reputasi yang baik;

2) Rasanya aman untuk menyelesaikan transaksi; 3) Informasi pribadi saya terasa aman; 4) Menciptakan rasa personalisasi; 5) Menyampaikan rasa komunitas; 6) Membuatnya mudah untuk berkomunikasi dengan organisasi; dan 7) Saya merasa yakin bahwa barang / jasa akan disampaikan seperti yang dijanjikan

d. Kepuasan Pengguna/ Keseluruhan (User Satisfaction /Overall)

Overall disini lebih diartikan sebagai overall terhadap User Satisfaction kepuasan pengguna dan berperan sebagai variabel dependen (Nora: 2015).

Indikator dari Overall / User Satisfaction yaitu: 1) Tampilan website secara keseluruhan baik

\section{Hasil Penelitian dan Diskusi}

\section{Hasil Pengukuran Kualitas LayananWebsite LP2M UIN Raden Fatah Palembang}

Berdasarkan hasil perhitungan distribusi frekuensi dari tiap-tiap variabel, didapatkan nilai rata-rata data jawaban responden pada variabel kegunaan (usability) adalah sebesar 3,82, variabel kualitas informasi (information quality) adalah sebesar3,88,variabel kualitas interaksi layanan (service interaction qualitiy) adalah sebesar3,80,variabel overall diperoleh nilai mean adalah sebesar4. Untuk mengetahui nilai kualitas layananwebsite LP2M UIN Raden Fatah Palembang yang dihitung dengan menggunakan metode webqual 4.0, berikut perhitungannya:

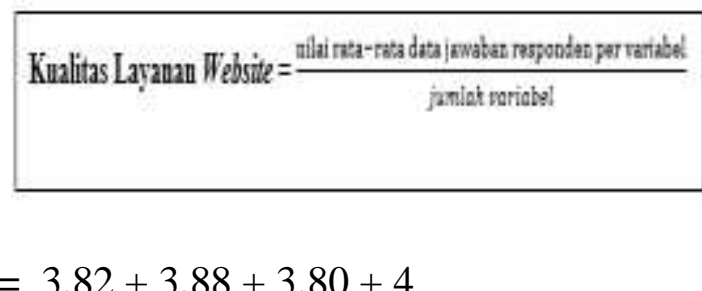

$=3,87$

Jurnal Intelektualita: Keislaman, Sosial, dan Sains

Volume 7, Nomor 1, Juni 2018 
Rahmawati dan Saipul Anwar

Analisis Pengukuran Kualitas Layanan Website LP2M UIN Raden Fatah Palembang

Menggunakan Metode Webqual 4.0

Hasil pengukuran menunjukkan tingkat setuju berdasarkan perhitungan skala likert dari angka 1 sampai 5, yang berarti bahwa kualitas layananwebsite LP2M UIN Raden Fatah Palembang berdasarkandata jawaban responden menyatakan setuju bahwa kualitas layananwebsite LP2M UIN Raden Fatah Palembang sudah sesuai dengan kepuasan pengguna.

\section{Hasil Uji Normalitas}

Berikut ini adalah hasil uji normalitas data Variabel Kegunaan, Kualitas Informasi, Kualitas Interaksi Layanan terhadap User Satisfaction / Overall.

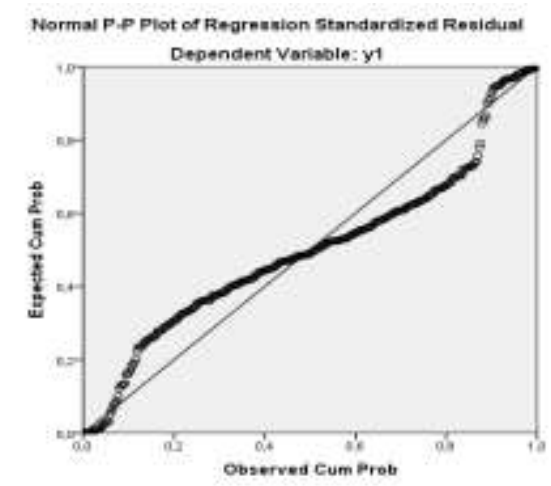

Gambar 2. Grafik normal P-P Plot pada variabel dependen User Satisfaction / Overall

Dengan melihat grafik normal probability plot, dapat diketahui bahwa titik-titik menyebar sekitar garis dan mengikuti garis diagonal. Maka dapat disimpulkan bahwa model layak karena memenuhi asumsi normalitas dan terdistribusi normal.

\section{Hasil Analisis Korelasi}

Hasil perhitungan tersebut dibuktikan kembali dengan bantuan SPSS 23 sebagai berikut:

\begin{tabular}{|c|c|c|c|c|c|}
\hline \multicolumn{6}{|c|}{ Correlations } \\
\hline & & U & 10 & $\mathrm{SIO}$ & 0 \\
\hline \multirow[t]{3}{*}{$U$} & Pearson Conelation & 1 & $438^{\prime \prime}$ & $.383^{\prime \prime}$ & $358^{\circ}$ \\
\hline & Sig. (2-taled) & & 600 & 000 & 000 \\
\hline & N & 334 & 334 & 334 & 334 \\
\hline \multirow[t]{3}{*}{12} & Pearson Comelation & $.438^{11}$ & 1 & $429^{\prime \prime}$ & $396^{\circ \prime}$ \\
\hline & Sig. (2-taled) & 500 & & 000 & 000 \\
\hline & $\mathrm{N}$ & 334 & 334 & 334 & 334 \\
\hline \multirow[t]{3}{*}{ S10 } & Pearsson Correlation & $.383^{\prime \prime}$ & $429^{\prime \prime}$ & 1 & $395^{\circ}$ \\
\hline & Sig. (2-taled) & 000 & .000 & & 000 \\
\hline & $N$ & 334 & 334 & 334 & 334 \\
\hline \multirow[t]{3}{*}{0} & Pearson Comelation & $358^{\prime \prime}$ & $396^{\prime \prime}$ & $.395^{\prime \prime}$ & 1 \\
\hline & Sig. (2-taled) & 500 & 600 & 000 & \\
\hline & $\mathrm{N}$ & 334 & 334 & 394 & 334 \\
\hline
\end{tabular}

Gambar 3. Output Hasil Analisis Korelasi Pearson Dengan SPSS 23

Angka korelasi antara variabel kegunaan (usability) dengan variabel kepuasan pengguna (overall / user satisfaction) adalah sebesar 0,358 yang berarti bahwa hubungan kedua variabel tersebut tergolong lemah. Hubungan bersifat lemah positif artinya terjadi 
hubungan searah yang lemah antara variabel kegunaan (usability) dengan variabel kepuasan pengguna (overall / user satisfaction), bila kegunaan (usability) semakin meningkat, maka kepuasan pengguna (overall / user satisfaction) ikut meningkat secara lemah.

Begitu juga dengan variabel kualitas informasi (information quality) dengan variabel kepuasan pengguna (overall / user satisfaction)adalah sebesar 0,396 danvariabelkualitas layanan interaksi (Service interaction quality) dengan variabel kepuasan pengguna (overall / user satisfaction)adalah sebesar 0,395 yang berarti bahwa hubungan kedua variabel tersebut tergolong lemah positif.

\section{Hasil Koefisien Determinasi}

a. Koefisien determinasi kegunaan (usability) terhadap (user satisfaction/overall)

Kontribusi yang disumbangkan variabel kegunaan (usability) terhadap variabel (user satisfaction / overall) diketahui dari nilai koefisien determinasi yang nilai r nya didapat dari penghitungan korelasi pada Gambar 4. Berikut perhitungannya:

$$
\begin{aligned}
\mathrm{KD} & =(\mathrm{r})^{2} \times 100 \% \\
& =(0,358)^{2} \times 100 \% \\
& =12,8164 \% \\
& =12,8 \%
\end{aligned}
$$

Dari perhitungan tersebut dapat diketahui kontribusi yang disumbangkan variabel kegunaan (usability) terhadap variabel (user satisfaction/overall) adalah sebesar $12,8 \%$.

b. Koefisien determinasi kualitas informasi (information quality)terhadap (user satisfaction/overall)

Kontribusi yang disumbangkan variabel kualitas informasi (information quality) terhadap variabel (user satisfaction / overall) adalah sebesar 15,7\%.

c. Koefisien Determinasi Kualitas Interaksi Pelayanan (Service Interaction Quality) Terhadap (user satisfaction/overall)

Kontribusi yang disumbangkan variabel kualitas interaksi pelayanan (Service interaction quality) terhadap variabel (user satisfaction/overall) adalah sebesar $15,6 \%$. 
Rahmawati dan Saipul Anwar

Analisis Pengukuran Kualitas Layanan Website LP2M UIN Raden Fatah Palembang

Menggunakan Metode Webqual 4.0

\section{Hasil Hipotesis}

Berikut ini adalah hasil ringkasan pengujian hipotesis:

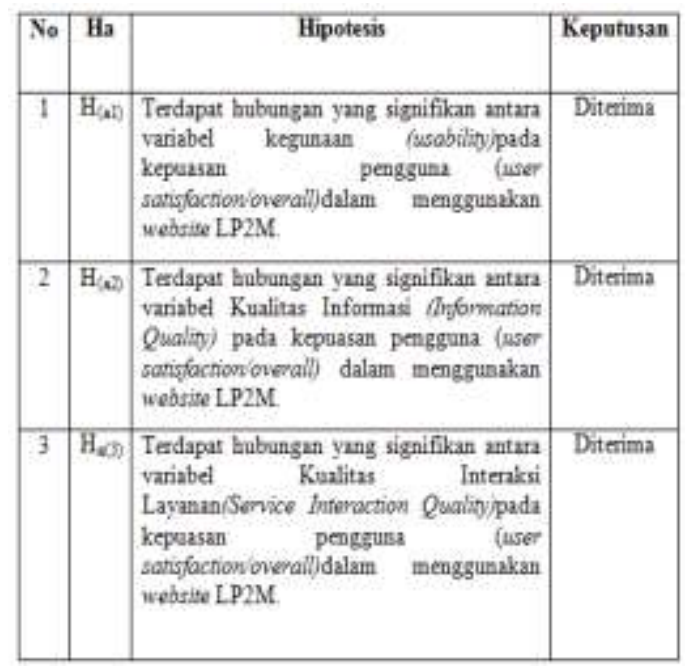

Tabel 1. Ringkasan hasil pengujian hipotesis

Dari Tabel 3. hasil pengujian hipotesis maka dapat disimpulkan bahwa ketiga hipotesis diterima yang berarti ketiga hipotesis terdapat hubungan yang signifikan dengankepuasan pengguna (overall / user satisfaction) dalam menggunakan website LP2M.

\section{Kesimpulan}

Berdasarkan hasil dan pembahasan dari bab sebelumnya maka dapat ditarik simpulan sebagai berikut:

1. Kualitas layananwebsite LP2M UIN Raden Fatah Palembang berdasarkandata jawaban responden menyatakan setuju bahwa kualitas layananwebsiteLP2M UIN Raden Fatah Palembang sudah sesuai dengan kepuasan pengguna sebesar 3,87.

2. Terdapat hubungan yang signifikan antara variabel kegunaan (usability) dengan kepuasan pengguna (User satisfaction / overall). Diperoleh nilai $t_{\text {hitung }}=6,99>t_{\text {tabel }}$ $=2,252$. Dengannilai kontribusi yang disumbangkan sebesar $12,8 \%$.

3. Terdapat hubungan yang signifikan antara variabel Kualitas Informasi (Information Quality) dengan kepuasan pengguna (User satisfaction / overall). Diperoleh nilai $\mathrm{t}_{\text {hitung }}=7,85783763>\mathrm{t}_{\text {tabel }}=2,252$. Dengannilai kontribusi yang disumbangkan sebesar $15,7 \%$.

4. Terdapat hubungan yang signifikan antara variabel Kualitas Interaksi Layanan (Service Interaction Quality) dengan kepuasan pengguna (User satisfaction/overall). Diperoleh nilai $t_{\text {hitung }}=7,83>\mathrm{t}_{\text {tabel }}=2,252$. Dengannilai kontribusi yang disumbangkan sebesar $15,6 \%$. 


\section{Daftar Pustaka}

[1] Barnes and Vidgen, "An Integrative Approach to the Assessment of E-Commerce Quality," Journal of Electronic Commerce Research, vol. 3, no. 3, 2002.

[2] J. Tarigan, "User Satisfaction Using Webqual Instrumet: A Research on stock exchange of Thailand (SET)," Jurnal Akutansi Dan Keuangan, vol. 10, no. 1, pp. 3437, 2008. 
Rahmawati dan Saipul Anwar

Analisis Pengukuran Kualitas Layanan Website LP2M UIN Raden Fatah Palembang

Menggunakan Metode Webqual 4.0

Jurnal Intelektualita: Keislaman, Sosial, dan Sains

Volume 7, Nomor 1, Juni 2018 